\title{
PERTANGUNGJAWABAN PIDANA DALAM KEADAAN DARURAT BENCANA COVID-19
}

\author{
Erwin Ubwarin ${ }^{1}$ Patrick Corputty ${ }^{2}$ \\ ${ }^{12}$ Fakultas Hukum Universitas Pattimura \\ Email: ${ }^{1}$ eubwarin@gmail.com, ${ }^{2}$ corputtyp@gmail.com
}

\begin{abstract}
ABSTRAK
Penanganan bencana non alam covid-19 harus dilakukan secara cepat yang tepat, namun ancaman pidana mati mengancam, terutama untuk pengambil kebijakan, namun pada sisi lain dengan dana penanganan yang begitu besar tentantunya menimbulkan potensi perbuatan korupsi. Tujuan penulisan ini untuk merumuskan pertanggungjawabn perbuatan pidana dalam perbuatan pidana, negara dalam keadaan bencana Covid-19. Metode yang dipakai adalah yuridis normatif, sumber bahan hukum primer, sekunder dan tresier, hasil penelitian yang dilakukan bahwa pebuatan pidana dalam keadaan bencana untuk keselamatan dan kesejahteraan orang banyak tidak dapat dimintai pertanggungjawaban pidana, dan dalam pasal 27 ayat 2 Peraturan Pemerintah Penganti Undang-Undang Nomor 1 Tahun 2020 dimaksudkan untuk pengambil kebijakan tidak melakukan perbuatan melawan hukum, dengan tetap beritikhad baik dan sesuai dengan peraturan perundangundangan. Maksud itikhad baik agar tidak memenuhi unsur sifat melawan hukum materiil. Walaupun Putusan Mahkamah Konstitusi sudah membatalkan sifat melawan hukum materiil namun Mahkamah Agung tetap menerapkan sifat melawan hukum materiil baik dari fungsi negatif maupun positif.

Kata kunci : Perbuatan Pidana, Bencana, Covid-19
\end{abstract}

\begin{abstract}
The handling of non-natural disasters covid-19 must be carried out quickly and appropriately, but the threat of capital punishment threatens, especially for policy makers, but on the other hand with such a large handling fund, of course it raises the potential for acts of corruption. The purpose of this paper is to formulate the responsibility of a criminal act in a criminal act, the state is in a state of disaster Covid-19. The method used is juridical normative, the source of primary, secondary, and legal legal materials, the results of research conducted that criminal acts in the event of a disaster for the safety and welfare of many people cannot be beld liable for criminal liability, and in article 27 paragraph 2 Government Regulation Substituting the Law Number 1 of 2020 is intended for policy makers not to commit acts against the law, with good intentions and in accordance with statutory regulations. The intention of good faith is that it does not fulfill the element of being against material law. Although the Constitutional Court Decision has overturned the nature of violating material law, the Supreme Court continues to apply the nature of violating material law both from negative and positive functions.

Keywords: Criminal Acts, Disasters, Covid-19
\end{abstract}

\section{A. PENDAHULUAN}

Jumlah korban yang berjatuhan baik dari masyarakat biasa maupun para tenaga kesehatan akibat virus SARS COV-2 atau yang dikenal dengan Covid-19. Cicero, mengatakan, "Salus populi suprema lex esto", keselamatan rakyat merupakan hukum tertinggi bagi suatu Negara. Pemerintah tidak tinggal diam, dari data yang dikeluarkan oleh Kementrian Keuangan, dana Rp. 405,1 Triliun (Kementrian Keuangan, 2020) dikeluarkan untuk menangagulangi pandemik ini, tentu dana yang luar biasa dalam penangganan Covid-19. Covid-19 merupakan singkatan dari Corona (CO), Virus (VI), Disease (D, penyakit) yang ditemukan pada Tahun 2019.

Presiden mengeluarkan Peraturan Pemerintah Penganti Undang-undang Nomor 1 Tahun 2020 untuk mempercepat penanganan Covid-19 dan menstabilkan perekonomian Negara.. Namun Pasal 27 menimbulkan perdebatan di kalangan ahli hukum tentang apakah ada kekebalan di dalam pasal tersebut.

Sementara untuk penanganan dalam Negara dalam keadaan bencana diatur dalam 
Pasal 2 ayat 1 Undang-undang Nomor 31 Tahun 1999 Pemberantasan Tindak Pidana Korupsi mengatur bahwa "setiap orang yang secara melawan hukum melakukan perbuatan memperkaya diri sendiri atau oang lain atau suatu korporasi yang dapat merugikan keuangan Negara atau perekonomian Negara, dipidana dengan pidana penjara seumur hidup atau pidana penjara paling singkat 4 (empat) tahun dan paling lama 20 (dua puluh) tahun dan denda paling sedikit Rp. 200.000.000,- (dua ratus juta rupiah) dan paling banyak Rp. 1.000.000.000,- (satu milyar rupiah)

Pasal 2 ayat 2 Undang-undang Nomor 31 Tahun 1999 Pemberantasan Tindak Pidana Korupsi mengatur bahwa Dalam hal tindak pidana korupsi sebagaimana dimaksud dalam ayat (1) dilakukan dalam keadaan tertentu pidana mati dapat dijatuhkan. Keadaan tertentu yang dimaksud adalah pada waktu negara dalam keadaan bahaya sesuai dengan undang-undang yang berlaku, pada waktu terjadi bencana alam nasional, sebagai pengulangan tindak pidana korupsi, atau pada waktu negara dalam keadaan krisis ekonomi dan moneter. ${ }^{1}$

Keppres 11 tahun 2020 tentang Penetapan Kedaruratan Kesehatan Masyarakat Corona Virus Disease 2019 (COVID-19), dengan Keppres ini Indonesia berada dalam staus bencana non-alam, tentunya akan menumbulkan permasalahan hukum. Hal ini yang membuat para pengambil kebijakan tentunya merasa takut, karena dihantui hukuman mati dalam Pasal 2 ayat 2 Undang-Undang Nomor 31 Tahun 1999.

Mulai dari pemberiaan bantuan sosial, pengadaan alat kesehatan, pengadaan barang dan jasa tentunya berpotensi terjadi korupsi jika ada oknum-oknum yang diduga ingin memanfaatkan keadaan status bencana.

Komisi Pemberantasan Korupsipun bergerak cepat dengan memberikan peringatan melalui Surat Edaran Nomor 8 tentang Penggunaan Anggaran Pelaksanaan

${ }^{1}$ Erwin Ubwarin, Yonna Beatrix Salamor, Mekanisme Pengembalian Kerugian Negara oleh Terpidana yang Meninggal Dunia Pasca Putusan Mahkamah Konstitusi Nomor 25/PUU-XIV/2016, Jurnal Muara Ilmu Sosial, Humaniora, dan Seni Volume 1 Nomor 1 Tahun 2017 hal. 53
Pengadaan Barang/Jasa Dalam Rangka Percepan Penanganan Corona Virus Disease 2019 (Covid-19) Terkait Dengan Pecegahaan Korupsi, Surat Edaran Nomor 11 tentang Penggunaan Data Terpadu Kesejahteraan Sosial (DTKS) dan data non-DTKS dalam pemberiaan Bantuan Sosial ke Masyarakat.

Berdasarkan latar belakang di atas penulis tertarik menulis tentang apakah 1 . kualifikasi perbuatan pidana dalam keadaan bencana non alam Covid-19, 2. Perbuatan apa saja yang dapat dimintai perbuatan pidana.

\section{B. METODE PENELITIAN}

1. Jenis Penelitian

Jenis penelitian yang digunakan dalam penelitian ini adalah penelitian hukum normatif atau penelitian hukum kepustakaan (Library research). ${ }^{2}$ Penelitian hukum normatif mengkaji hukum yang dikonsepsikan sebagai norma atau kaidah yang berlaku. Norma hukum yang berlaku itu berupa norma hukum positif tertulis bentukan lembaga perundang-undangan (undang-undang dasar, kodifikasi ,undang-undang, peraturan pemerintah, dan sebagainya). ${ }^{3}$

\section{Tipe Penelitian}

Tipe penelitian yang dipakai dalam penulisan ini bersifat Deskriptif Analitis. ${ }^{4}$ Dengan alasan bahwa hasil yang didapatkan dari studi kepustakaan selanjutnya dianalisis dan dibahas dengan menggunakan alur pembahasan secara sistemtis didalam beberapa bab. Kemudian hasil analisis pembahasan tersebut dideskripsikan untuk mempermudah penarikan kesimpulan dan pengajuan saran.

\section{Sumber Bahan Hukum}

Adapun yang menjadi sumber bahan hukum yang diperlukan dalam penelitian

${ }^{2}$ Soerjono Soekanto dan Sri Mamudji, Penelitian Hukum Normatif Suatu Timjanan Singkat, cetakan keempat, Raja Grafindo Persada, Jakarta, 1995, hal 13-14.

${ }^{3}$ Abdulkadir Muhammad, Hukum dan Penelitian Hukum, cetakan 1, Citra Aditya Bakti, Bandung, 2004, hal 52.

${ }^{4}$ Roni Hanitjo Soemitro, Metodologi Penelitian Hukum dan Yurimetri, Ghalia Indonesia, Jakarta, 1980. hal 12. 
ini yaitu bahan hukum sekunder berdasarkan studi pustaka/studi literatur (library research). Sumber bahan hukum tersebut diklasifikasikan antara lain;

a. Bahan Hukum Primer

Bahan hukum primer diperoleh melalui studi kepustakaan atau penelitian studi kepustakaan. Bahan hukum ini ialah yang mempunyai otoritas. Bahan hukum ini terdiri atas peraturan perundangundangan sesuai hierarki, yaitu :

1) Undang-Undang Dasar Negara Republik Indonesia Tahun 1945

2) Kitab Undang-undang Hukum Pidana

3) Perpu Nomor 1 Tahun 2020

b. Bahan Hukum Sekunder

Bahan hukum sekunder meliputi bahanbahan yang mendukung bahan hukum primer seperti buku teks, artikel, dalam berbagai majalah ilmiah atau jurnal hasil penelitian dibidang hukum, makalahmakalah yang disampaikan dalam berbagai bentuk pertemuan seperti diskusi, seminar, dan lain-lain.

\section{c. Bahan Hukum Tersier}

Bahan hukum tersier diperoleh dari majalah-majalah hukum, brosur, internet, kamus, dan faktor-faktor hukum yang terjadi dalam praktek.

4. Teknik Pengumpulan dan Analisis Bahan Hukum

Sesuai dengan sifat penelitian maka analisis dan teknik pengumpulan bahan hukum yang dipakai adalah Analisis Kualitatif yaitu dengan cara mempelajari dan memahami data yang ada selanjutnya dianalisis dengan metode induktif dan deduktif sehingga dapat ditarik kesimpulan dalam rangka menjawab permasalahan dalam penulisan ini. ${ }^{5}$

\section{PEMBAHASAN}

Orang kaya baru dan orang miskin baru sering membuat bantuan tidak tepat

${ }^{5}$ Soerjono Soekamto, Pengantar Penelitian Hukum, Rajawali Press, Jakarta, 2003, hal 15. sasaran, diberapa tempat ditemukan salah pemberiaan bantuan bahkan ada yang tidak mendapatkan bantuan, pada kasus yang berbeda ada daerah yang mau dilakukan pemilihan kepala daerah, bupati, walikota dan gubernur memanfaatkan moment bencana untuk penyaluran bantuan sebagai pecintraan menjelang pemilihan kepala daerah. Pengadaan alat kesehatan yang bermasalah karena banyak mafia yang bermain dalam pengadaan barang dan jasa, apalagi pengadaan bantuan langsung tunai dan bantuan sembako akan bukan pengadaan bangunan yang dapat diukut bukti fisiknya dikemudian hari.

Pasal 27 ayat 2 Peraturan Pemerintah Penganti Undang-undang mengatur bahwa

Anggota KSSK, Sekretaris KSSK, anggota secretariat KSSK, dan pejabat atau pegawai Kementerian Keuangan, Bank Indonesia, Otoritas Jasa Keuangan, serta Lembaga Penjamin Simpanan, dan pejabat lainnya, yang berkaitan dengan pelaksanaan Peraturan Pemerintah Pengganti Undang-Undang ini, tidak dapat dituntut baik secara perdata maupun pidana jika dalam melaksanakan tugas didasarkan pada iktikad baik dan sesuai dengan ketentuan peraturan perrrndang-undangan.

Komisi Pemberantasan Korupsi (KPK) tidak tinggal diam melihat Peraturan Pemerintah Nomor 2 Tahun 2020, dan potensi korupsi yang akan terjadi lewat Surat Edaran Nomor 8 Tahun 2020 ada beberapa hal yang dilarang :
a. Tidak
melakukan persengkongkolan/kolusi dengan penyedian barang/jasa.
b. Tidak memperoleh kickback dari penyedia
c. Tidak mengandung unsur penyuapan
d. Tidak mengandung unsur gratifikasi
e.Tidak mengandung untuk adanya benturan kepentingan dalam pengadaan
f. Tidak mengandung unsur kecurangan dan atau mal- administrasi.
g. Tidak berniat jahat dengan memanfaatkan kondisi darurat. 
h. Tidak membiarkan terjadinya tindak pidana korupsi.

Sedangan dalam surat Edaran 11 Tahun 2020 mengatur yang pada intinya

a. Pendunaan Data DTKS dalam penyaluran bantuan

b. Bahwa jika data DTKS berbeda dengan dilapangan harus segera melakukan perbaikan

c. Pengunaan Nomor Induk Kependudukan Bagi Penerima Bantuan Sosial.

d. Tranparasi dan akuntabilitas dalam pemberiaan bantuan sosial

e. Peran serta masyarakat dalam pemberian bantuan sosial.

Pada penulisan ini penulis membahas tentang perbuatan pidana dalam keadaan darurat.

Keadaan darurat (noodtoestand) tidak di atur secara khusus dalam Kitab UndangUndang Hukum Pidana, menurut sejarah perundang-undangan Kitab Undang-Undang Hukum Pidana Belanda, pengaturan keadaan darurat(noodtoestand) dianggap tidak perlu. Apabila fakta hukum yang hakikatnya lebih dekat dengan keadaan darurat (noodtoestand) maka akan dikualifikasikan daya paksa (overmacht). Oleh karena itu, keadaan darurat (noodtoestand) sebagai alsan penghapus pidana selalu dikaitan dengan daya paksa (overmacht). ${ }^{6}$

Menurut D. Scaffmeister, dkk keadaan darurat adalah alasan pembenar, yaitu kalo seseorang dihadapkan pada suatu keputusan untuk memilih antara melakukan delik atau merusak kepentingan yang lebih besar. Dalam Keadaan demikian dibenarkan oleh hukum kalau orang melakukan delik agar kepentingan yang lebih besar tersebut terlindungi. Oleh karena itu, yang dilakukan untuk melindungi kepentingan yang lebih besar tidak dapat dipidana. Ada anak kecil yang tercebut didalam kolam renang anak, kemudian ada orang dewasa yang menolong, padahal di depannya sudah tertulis kolam khusus anak, orang dewasa dilarang untuk berenang disini. ${ }^{7}$

Putusan Hoge Raad tetang Putusan Optisien (putusan ahli kacamata, HR 15

${ }^{6}$ I Gede Widhiana Suarda, Hukum Pidana : Materi Pengahapus, Peringan dan Pemberat Pidana. Bayumedia Publishing, Malang. 2012. hal 108

7 Ibid 109
Oktober 1923. Tukang kacamata melakukan pelanggaran peraturan Kotamadya Amterdam dengan tidak menutup toko kacamata dan tetap melayani pembeli yang membutuhkan kacamata. Ia melayani seorang yang baru saja kehilagan kacamatanya, dan harus membawa kedaraan untuk pulang, jika ia tidak mempunyai kacamata mata sudah pasti akan mengalami kecelakaan, Hoge Raad berpendapat bahwa pengadilan negeri tidak merusak secara yuridis pengertian daya paksa, oleh karena menurut sejarahnya, daya paksa meliputi keadaan darurat. ${ }^{8}$

Perbuatan pidana menurut Moeljatno berpendapat bahwa elemenelemen pembuat pidana adalah sebagai berikut :

1. Pembuat yang terdiri dari kelakuan dan akibat;

2. Hal ikwal atau kedaan menyertai perbuatan;

3. Keadaan tambahan yang memberatikan pidana

4. Unsur melawan hukum yang objektif

5. Unsur melawan hukum yang subjektif.

Dalam keadaan darurat maka kita akan melihat pada unsur ke empat dan unsur kelima.

Point ke-empat, unsur melawan hukum yang objektif atau objektif onrechtselemet adalah perbuatan nyata yang secara kasat mata memenuhi unsur delik. Jika perbuatan tersebut memenuhi unsur pasal maka unsur ini terpenuhi.

Berikutnya pada point ke-lima, unsure melawan hukum yang subjektif atau subjektif onrechtselemet, adalah niat atau sikap batin dari pelaku ketika melakukan tidakan atau dikenal dengan mensrea. Ketika seseorang dalam keadaan darurat bencana melanggar peraturan perundang-undangan maka perbuatannya tersebut bukanlah tindak pidana.

Jika dilihat dari pandangan sifat melawan hukum formil dan sifat melawan hukum materiil. Tindakan melanggar peraturan perundang-undangan pada saat bencana alam tentunya memenuhi sifat melawan hukum secara formil, namun sikap

${ }^{8}$ Eddy O. S. Hiariej, Prinsip-Prinsip Hukum Pidana. Cahaya Atma Pustaka. Yogyakarta. hal 271 
batin dan tujuan mengambil kebijakan untuk menolong orang banyak atau kebijakan yang menguntungkan masyarkat banyak dalam penanganan bencana, maka hal tersebut tentu tidak memenuhi sifat melawan hukum materiil atau materiel wederrechtelijkheid.

Maka menurut penulis maksud dari Pasal 27 ayat 2 Perpu Nomor 1 Tahun 2020 adalah untuk mengingatkan semua pengambil kebijakan dalam penanganan Covid-19 agar sesuai dengan itikad baik, agar tidak terpenuhinya unsur sifat melawan hukum materiil.

Putusan Mahkamah Konstitusi No. 003/PUU-IV/2006 membatal sifat melawan hukum materiil pada Pasal 2 ayat 1, namun pada prakteknya Mahkamah Agung masih mempraktekan sifat melawan hukum materiil dalam Putusan Mahkamah Agung pasca putusan Mahkamah Kostitiusi (vide Sema Nomor 7 Tahun 2012). Penulis sependapat dengan Mahkamah Agung bahwa demi rasa keadilan tetap mempertahankan unsur melawan hukum materiil, dan putusan Mahkamah Konstitusi tidak bersifat mengikat hakim karena hakim bersifat merdeka dalam mengambil keputusan sesuai dengan Pasal 24 ayat 1 Undang-undang Dasar 1945.

Setiap masyarakat Indonesia mempunyai hak mendapatkan keadilan sebagai bentuk dari hak asasi. ${ }^{9}$

Jadi perbuatan pidana yang dilakukan pejabat pada saat status darurat untuk kepentingan dan keuntungan masyarakat banyak tentunya tidak bisa dituntut pidana karena tidak memenuhi unsur sifat melawan hukum materiiel. Maka putusan yang diambil adalah putusan lepas dari segala tuntutan (onslag van recht vervolging).

\section{KESIMPULAN}

1. Perbuaan pidana dalam penanganan Covid-19 diancam dengan pidana mati dalam pasal 2 ayat 2 UndangUndnang Nomor 31 Tahun 1999 tentang Pemberantasan Tindak Pidana Korupsi.

9 Jennifer Ingelyne Nussy, Mekansime Komisi Pemberantasan Korupsi Dalam Proses Penyadapan Dilihat Dari Perspektif Hak Asasi Manusia, Jurnal Belo, Volume 5 Nomor 2, Tahun 2020. hal 74
2. Pasal 27 ayat 2 Peraturan Pemerintah Penganti Undang-Undang Nomor 1 Tahun 2020 adalah mengingatkan pengabil kebijkan agar tetap menggunakan itikhad baik dan sesuai dengan peraturan perundangundangan agar tidak dituntut pidana.

3. Melawan hukum materiil dalam penagganan bencana alam penting diterapkan untuk rasa keadilan walaupun ada Putusan Mahkamah Konstitusi No. 003/PUU-IV/2006. Hal ini sejalan dengan Putusan HR tentang Tukang Kacamata.

4. Namun Jika perbuatan untuk keselamatan, kesejahteraan dan kepentingan masyarakat banyak, tentunya tidak memenuhi melawan hukum materiil dalam fungsi negatif.

5. Dan bila ada perbuatan hukum pidana yang tidak diatur undangundang namun melawan hukum materiil dalam fungsi positif.

\section{E. DAFTAR PUSTAKA}

Abdulkadir Muhammad, Hukum dan Penelitian Hukum, cetakan 1, Citra Aditya Bakti, Bandung, 2004.

Eddy O. S. Hiariej, Prinsip-Prinsip Hukum Pidana. Cahaya Atma Pustaka. Yogyakarta. 2018

Erwin Ubwarin, Yonna Beatrix Salamor, Mekanisme Pengembalian Kerugian Negara oleh Terpidana yang Meninggal Dunia Pasca Putusan Mahkamah Konstitusi Nomor 25/PUU-XIV/2016, Jurnal Muara Ilmu Sosial, Humaniora, dan Seni Volume 1 Nomor 1 Tahun 2017.

Jennifer Ingelyne Nussy, Mekansime Komisi Pemberantasan Korupsi Dalam Proses Penyadapan Dilihat Dari Perspektif Hak Asasi Manusia, Jurnal Belo, Volume 5 Nomor 2, Tahun 2020.

I Gede Widhiana Suarda, Hukum Pidana : Materi Pengahapus, Peringan dan Pemberat Pidana. Bayumedia Publishing, Malang. 2012. 
Roni Hanitjo Soemitro, Metodologi Penelitian Hukum dan Yurimetri, Ghalia Indonesia, Jakarta, 1980.

Soerjono Soekanto dan Sri Mamudji, Penelitian Hukum Normatif Suatu Tinjauan Singkat, cetakan keempat, Raja Grafindo Persada, Jakarta, 1995,

Soerjono Soekanto, Pengantar Penelitian Hukum, Rajawali Press, Jakarta, 2003,

\section{Peraturan Perundang-undangan}

Undang-Undang Dasar Negara Republik Indonesia Tahun 1945

Kitab Undang-undang Hukum Pidana

Perpu Nomor 1 Tahun 2020 tentang Kebijakan Keuangan Negara dan Stabilitas Sistem Keuangan Untuk Penanganan Pandemi Corona Virus Diasease 2019 (Covid-19) dan/atau Dalam Rangka Menghadapi Ancaman Yang Membahayakan Perekonomian Nasional dan/atau Stabilitas Sistem Keuangan. 